\title{
At the Front: common traitors in West German war films of the 1950s
}

Article

Accepted Version

Wölfel, U. (2015) At the Front: common traitors in West German war films of the 1950s. Modern Language Review, 110 (3). pp. 739-758. ISSN 0026-7937 doi:

https://doi.org/10.5699/modelangrevi.110.3.0739 Available at https://centaur.reading.ac.uk/40673/

It is advisable to refer to the publisher's version if you intend to cite from the work. See Guidance on citing.

To link to this article DOI: http://dx.doi.org/10.5699/modelangrevi.110.3.0739

Publisher: Modern Humanities Research Association

All outputs in CentAUR are protected by Intellectual Property Rights law, including copyright law. Copyright and IPR is retained by the creators or other copyright holders. Terms and conditions for use of this material are defined in the End User Agreement.

\section{www.reading.ac.uk/centaur}

\section{CentAUR}

Central Archive at the University of Reading

Reading's research outputs online 


\section{AT THE FRONT: COMMON TRAITORS IN}

WEST GERMAN WAR FILMS OF THE 1950s

Erst im militärischen Geheimnis kommt das Staatsgeheimnis zu sich selbst; da der Krieg als permanenter und totaler Zustand vorausgesetzt wird, läßt sich jeder beliebige Sachverhalt unter militärische Kategorien subsumieren: dem Feind gegenüber hat alles als Geheimnis und jeder Bürger als potentieller Verräter zu gelten.

(HANs Magnus ENZENSBERGER)

Die alten Krieger denken immer an die Kameraden, die gefallen sind, und meinen, ein Deserteur sei einer, der sie verraten hat.

(LUDWIG BAUMANN)

\section{Introduction}

Margret Boveri, in the second volume of her treatise on Treason in the 20th Century, notes with respect to German resistance against National Socialism that the line between ethically justified and unethical treason is not easily drawn. ${ }^{1}$ She cites the case of General Hans Oster, deputy head of the Abwehr under Admiral Canaris. Oster had repeatedly leaked military information to Western governments warning them of the dates of German attacks, and Boveri contends that his opposition to the Nazi regime came close to treason not just in what

\footnotetext{
${ }^{1}$ Margret Boveri, Der Verrat im 20. Jahrhundert. Für und gegen die Nation: Das unsichtbare Geschehen (Hamburg: Rowohlt, 1956), p. 56.
} 
she calls the 'Hitler-Freisler' sense. ${ }^{2}$ The underlying assumption here is that while jurisdiction in the Third Reich as represented by Roland Freisler (President of the Volksgerichtshof, or People's Court) perpetrated injustice, some of its victims might nonetheless be guilty and Hans Oster might have been a real or 'unethical traitor'. Boveri bases the difference between 'ethical' and 'unethical treason' on the distinction between treason directed against the National Socialist state (Hochverrat) and treason involving cooperation with the enemy, which puts the nation at risk (Landesverrat). ${ }^{3}$ This distinction is already part of Boveri's source, namely Gerhard Ritter's discussion of Oster. In Ritter's assessment, Oster had committed treason out of moral outrage at the injustice of the Nazis' war of aggression. Faced with 'das offenkundige Verbrechen des Überfalls auf friedliche Nachbarvölker', ${ }^{4}$ Oster had disregarded what Ritter calls 'sham law'. While such behaviour towards the other is marked as highly ethical, in the eyes of Ritter it is still not beyond doubt:

Trotzdem bleibt die Frage noch offen, ob das Mittel, das Oster gegen diese völkerrechtswidrigen Gewalttaten einsetzte, in jedem Sinn gerechtfertigt war. Landesverrat, hat man in dem bekannten Braunschweiger Remer-Prozeß geurteilt, setzt böse Absicht voraus, dem eigenen Lande zu schaden. Daß Oster seinem Deutschland nicht schaden, sondern nützen wollte, bedarf keiner Diskussion. Aber hat er nicht wissentlich der deutschen Wehrmacht geschadet, indem er sie in erhöhte Gefahr brachte? Ging nicht die nächste Pflicht,

\footnotetext{
${ }^{2}$ Ibid, p. 55.

${ }^{3}$ For the definition of both terms see Gesetz zur Änderung des Strafrechts und des Strafverfahrens vom 24. April 1934 on www.documentarchiv.de.

${ }^{4}$ Boveri, Der Verrat im 20. Jahrhundert, p. 55.
} 
die gegen die eigenen Volksgenossen, die eigenen Kameraden, der gegen fremde Völker voran $?^{5}$

Boveri pursues this question further in her subsequent discussion of the resistance of the Rote Kapelle organization. Her focus on the distinction between those members of the group who cooperated with the (Soviet) enemy and those who did not provides an answer to Ritter's question: resistance against National Socialism was legitimate but became unethical where it helped the other before the self. ${ }^{6}$

\footnotetext{
${ }^{5}$ Ibid., p. 55. Boveri quotes from Gerhard Ritter, Carl Friedrich Goerdeler und die deutsche Widerstandsbewegung (Stuttgart: Deutsche Verlags-Anstalt, 1954).

${ }^{6}$ The Rote Kapelle served as a standard example of unethical treason at the time, based on the
} group's presentation as part of a Soviet-organized espionage network. This view was publically propagated after 1945 in talks, lectures, and brochures by, for example, former Oberstkriegsgerichtsrat Manfred Roeder who had acted as prosecutor against the Rote Kapelle in 1942. Despite post-war accusations arising from his role as prosecutor at the Reichskriegsgericht Roeder was exonerated in 1951 by the district attorney of Lüneburg while his victims were confirmed as lawfully sentenced to death: "'Blut deutscher Soldaten" sei “unnütz und unschuldig durch ihre Verratshandlung geflossen”". Roeder's public defamation had, according to Heinrich Grosse, a remarkable impact: 'Seine Aussagen und diffamierenden Urteile über die Männer und Frauen der Widerstandsgruppe um Hans von Dohnanyi und der "Roten Kapelle" wurden nicht nur von Journalisten, sondern auch von Historikern unkritisch übernommen. So stützt sich der bekannte Historiker Gerhard Ritter in seinem Werk Carl Goerdeler und die deutsche Widerstandsbewegung auf Roeder's Schrift Die Rote Kapelle und macht sich dessen These vom Landesverrat zu eigen'. See Heinrich 
The debate on resistance in terms of treason that Boveri echoes here was extensive in the early years of the Federal Republic, ${ }^{7}$ and it is therefore not surprising that it was also taken up in a number of West German war films of the so-called Militär- or Kriegsfilmwelle of the $1950 \mathrm{~s} .{ }^{8}$ These films are generally known for their apologetic and self-righteous attitude, for avoiding the topic of the Holocaust, ignoring the nature of the Second World War as a war of annihilation, romanticising it as ahistorical tragedy or fate, and cleansing the Wehrmacht off its involvement in National Socialism and of responsibility for the horrors of the war. ${ }^{9}$ As part of this attempt at German exculpation, the arguments for or against treason formed part of a strategy of safeguarding Germany against charges of war crimes and atrocities, as has been demonstrated in the case of screen representations of the conservative

Grosse, 'Ankläger von Widerstandskämpfern und Apologet des NS-Regimes nach 1945 Kriegsgerichtsrat Manfred Roeder', Kritische Justiz, 38 (2005), 36-55 (p. 55).

${ }^{7}$ See Helmut Kramer, 'Das letzte Gefecht um den "Kriegsverrat” im NS-Staat', Kritische Justiz, 42 (2009), 89-96.

${ }^{8}$ The term is widely used for the 224 or so international and German war films (according to statistics from the Freiwillige Selbstkontrolle der Filmwirtschaft, or Voluntary SelfRegulation of the Movie Industry) screened in West German cinemas between 1951 and 1959. See Manfred Barthel, So war es wirklich: Der deutsche Nachkriegsfilm (Munich: Herbig, 1986), p. 260.

${ }^{9}$ Philipp von Hugo, 'Kino und kollektives Gedächtnis? Überlegungen zum westdeutschen Kriegsfilm der fünfziger Jahre', in Krieg und Militär im Film des 20. Jahrhunderts, ed. by Bernhard Chiari, Matthias Rogg, and Wolfgang Schmidt (Munich: Oldenburg, 2003), pp. 453-76 (p.461). 
military resistance. ${ }^{10}$ Yet the significance of the traitor figure and its discursive position goes beyond the restoration of blamelessness because it also opens up memories, corroded notions of self and political conflicts on screen. In this article, I look at screen traitors not as figures of self-justification but as figures of conflict that contribute to a debate on national thresholds and responsibilities. My claim is that what was perceived and discussed as treason facilitated an examination of more complex problems.

A preoccupation with the screen elite traitor à la Stauffenberg has meant that other traitor figures have been ignored: my starting point, therefore, is that the figure of the elite traitor is intrinsically linked to another concept of alleged treason, the hitherto overlooked figure of the common traitor. I want to argue that these two figures are complementary in that they explore the two contrasting kinds of treason considered by Boveri and others, Hochverrat and Landesverrat. They thereby mark opposite poles between which treason is acted out - self and other - and gradually (re)negotiate perceptions of Germany in relation to its war-time others.

Sociology defines betrayal - and treason as a kind of betrayal - as a 'breach of trust' in which 'an overstepping of a We-boundary [is involved]', ${ }^{11}$ or in which 'a sense of an imagined community [...] and of collective memories and identities [is violated]' ${ }^{12}$ 'Betrayal involves the issue of morality in the most intimate way: It touches issues of trust, loyalty,

${ }^{10}$ See Wolfgang Becker and Norbert Schöll, In jenen Tagen ... Wie der deutsche Nachkriegsfilm die Vergangenheit bewältigte (Opladen: Leske + Budrich, 1995), pp. 79-106. ${ }^{11}$ Malin Akerstrom, Betrayal and Betrayers: The Sociology of Treachery (New Brunswick and London: Transaction Publishers, 1991), p. 2.

${ }^{12}$ Ben-Yehuda Nachman, Betrayals and Treason: Violations of Trust and Loyalty (Westview Press: Oxford, 2001), p. 27. 
honesty, and commitment'. ${ }^{13}$ Within this broad definition, it is characteristic of the $1950 \mathrm{~s}$ screen elite traitor, the Hochverräter, that although he is 'overstepping a We-boundary', he nevertheless defines and justifies this breach in relation to the national self. On the other hand, the common traitor of 1950s cinema is a Landesverräter; he enters into relations with the other, violates the 'sense of an imagined community' (a national community), and puts it at risk, while the elite traitor in fact tries to protect it. Accordingly, the elite traitor is presented as ethically more acceptable, indeed as a resistance fighter, while the common traitor embodies the allegedly unethical counter-position. My hypothesis is, however, that it is the figure of the common traitor that has the potential to advance and change the discourse on national identity by its focus on the other.

In the early 1950s the relationship between traitor and self-community dominates the screen discourse on post-war morality, while the relation between traitor and other emerges only gradually as morally significant but then marks the potential to reverse the definition of ethical traitor: from being someone who commits treason in the interest of the self, the ethical traitor becomes someone who commits treason because of a moral responsibility towards the other. Thus the traitor's transgression functions not simply as a violation of self but as a redirection and renewal of social and ethical values. The traitor appears as a potential reformer who 'may fulfil an important social function of introducing vital change into our cultures - a kind of positive mutation that helps to change the moral boundaries of society'. ${ }^{14}$ Crystal Parikh sees betrayal similarly as potentially 'perform[ing] a cultural critique of the

\footnotetext{
${ }^{13}$ Ibid., p. 28.

${ }^{14}$ Nachman, Betrayals and Treason, p. 112.
} 
social conditions', as a 'possibility for agency and transformation', ${ }^{15}$ which becomes available through the self's accountability to the other. ${ }^{16}$

My discussion starts with a brief overview of the familiar figure of the elite traitor in Canaris, Des Teufels General, Der 20. Juli, and Es geschah am 20. Juli. ${ }^{17}$ It then proceeds to the figure of the common traitor, whose features and functions are explored in detail in three feature films: part 2 of 08/15, Der Arzt von Stalingrad, and Unruhige Nacht. ${ }^{18}$ My focus is on the common traitor as a counter-position to the elite traitor: first with regard to his negative political and cultural perception as unethical, and second with regard to his potential for political and cultural change. These two characteristics make the common traitor a figure of particular ambivalence. They are rooted in his function both as gateway for the other as enemy and as victim of German perpetration, which turns the common traitor into a threat as well as into a hidden reminder of German guilt and responsibility. This becomes most visible in Harnack's Unruhige Nacht, as the film tries to unlock human sympathy with the victims of German aggression and at the same time adheres to the strict divide between friend and enemy, self, and other. The first real questioning of this divide occurs on television rather

${ }^{15}$ Crystal Parikh, An Ethics of Betrayal: The Politics of Otherness in Emergent U.S.

Literatures and Culture (New York: Fordham University Press, 2009), p. 2.

${ }^{16}$ Ibid., p. 6.

${ }^{17}$ Canaris, dir. by Alfred Weidemann (Atlas-Filmverleih GmbH, 1954); Des Teufels

General, dir. by Helmut Käutner (Europa-Filmverleih GmbH, 1955); Der 20. Juli, dir. by Falk Harnack (Herzog Filmverleih GmbH, 1955); Es geschah am 20. Juli, dir. by W.G. Pabst (Neue Filmverleih GmbH, 1955).

${ }^{18}$ 08/15 - II. Teil, dir. by Paul May (Gloria-Filmverleih GmbH, 1955); Der Arzt von Stalingrad, dir. by Geza von Radvanyi (Gloria-Filmverleih GmbH, 1958); Unruhige Nacht, dir. by Falk Harnack (Europa-Filmverleih GmbH, 1958). 
than in the cinema with the mini-series Am grünen Strand der Spree. ${ }^{19}$ My final discussion looks at the shift towards the acknowledgement of responsibility for the other in this early TV production; again the figure of the traitor helps to facilitate the change.

West German war films of the 1950s have received extensive critical attention. While for a long time they were discussed in relation to strategies of West German selfrighteousness and suppression of guilt and responsibility, they have more recently been acknowledged as hybrid products of national transformation in which cultural and political changes from the Third Reich to a new democratic West Germany gradually play out. In this sense, they are part of a 'necessarily imperfect process of cultural transmission or adaptation' and 'the question then becomes: Which aspects of a discourse survive, and which are subject to renewal or rejection? ${ }^{20}$ This article investigates exactly such a process of cinematic transmission by looking at the 'common traitor' as an element that disrupts the dominant discourse of blamelessness and points to an unresolved conflict.

\section{The Elite Traitor}

In his review of Decision before Dawn, ${ }^{21}$ the film that Sabine Hake identifies as having generated the wave of German treason-films, ${ }^{22}$ Paul Hühnerfeld, writing in Die Zeit, posed a moral question in his title: 'Kann Verrat gut sein?' He subsequently discussed not the

\footnotetext{
${ }^{19}$ Am grünen Strand der Spree, dir. by Fritz Umgelter (ARD, 1960).

${ }^{20}$ Jennifer Kapzynski, 'Armchair Warriors: Heroic Postures in the West German War Film', in Screening War: Perspectives on German Suffering, ed. by Paul Cooke and Marc Silberman (Rochester, NY: Camden House, 2010) pp. 17-35 (p. 19).

${ }^{21}$ Decision before Dawn, dir. by Anatole Litvak (Twentieth Century Fox, 1951).

${ }^{22}$ Sabine Hake, Screen Nazis: Cinema, History, and Democracy (Madison, London: The University of Wisconsin Press, 2012), p. 77.
} 
cinematic qualities of this 20th Century Fox production, but the conditions under which treason might be justified. Hühnerfeld's argument revolved around a notion of Germany's military past employed to confirm the right of disobedience for the individual soldier retrospectively:

Das Wesen des Preußischen ist nicht gekennzeichnet durch blinden Gehorsam. [...] Das eigentlich Preußische ist mehrschichtig: es hat die absolute Freiheit des einzelnen nicht ausgeschaltet, sondern in den Dienst der Sache gestellt. Aber es muß immer schon mit Situationen gerechnet worden sein, in denen es gerade für das allgemeine Wohl für besser gehalten wurde, wieder an die Freiheit des einzelnen zu appellieren: [...] Bevor das Preußische und die echte Vaterlandsliebe vom Nationalismus verschluckt wurden, war es zwar ungewöhnlich, aber nicht unmöglich daß Soldaten, gerade weil sie Soldaten waren, ,Verrat‘ übten. Sie wußten noch, daß die Treue, als Tugend so hoch angeschrieben im soldatischen Bereich, erstens eine Treue zum Wohl des Landes, zweitens eine Treue zu sich selbst und erst drittens eine Treue zum Landesherrn war, der ja nach einem Ausspruch des größten Preußenkönigs nur Diener und Repräsentant des Landes und des einzelnen war. Sie wußten, daß der Landesherr überhaupt nur Treue beanspruchen könnte, wenn er die Bedingungen, die Friedrich II. an einen Herrscher stellte, erfüllte. ${ }^{23}$

With this stance, Hühnerfeld echoes a wider debate in which Hochverrat was retrospectively rooted in the national/Prussian past, while Hitler was condemned as a 'sham leader' who could not claim loyalty. The debate was linked to the 20 July plot by high ranking Wehrmacht Officers around Stauffenberg. According to Douglas Peifer, a highly critical

\footnotetext{
${ }^{23}$ Paul Hühnerfeld, 'Kann Landesverrat gut sein?', Die Zeit, 13 November 1952 (http://www.zeit.de/1952/46/kann-landesverrat-gut-sein).
} 
evaluation of the Prussian military, including the Wehrmacht and its officer corps, had been encouraged by the Allies immediately after the war and had dominated the public sphere. ${ }^{24}$ However, in the context of the Cold War and West German rearmament, a re-evaluation of the role of the Prussian military took place during which official attacks from the Allies as well as the Adenauer government on the role of the German military ceased and efforts were focused on the reappraisal of the conservative military resistance of the men and women of 20 July. ${ }^{25}$ While many West Germans saw Stauffenberg and his group as base traitors, ${ }^{26}$ government and Allies began to propagate an interpretation according to which 'Stauffenberg and associates had been patriots who put Fatherland and honor over Führer and oath', ${ }^{27}$ thus offering a narrative of a moral military tradition that the new democratic West Germany could resume.

This reassessment of the high-ranking military was reflected in West German film production of the 1950s dealing with the Third Reich. In films such as Canaris, Des Teufels General, Der 20. Juli, and Es geschah am 20. Juli the focus was on resistance among the

${ }^{24}$ Douglas Peifer, 'Commemoration of Mutiny, Rebellion, and Resistance in Postwar Germany: Public Memory, History, and the Formation of "Memory Beacons", Journal of Military History, 65 (2001), 1013-52 (p. 1024).

${ }^{25}$ Ibid., p. 1036.

${ }^{26}$ For a discussion of the difficulties of this officially adopted legacy and particularly the difficulties it caused for the foundation of the Bundeswehr see David Clay Large, "“A Gift to the German Future?" The Anti-Nazi Resistance Movement and the West German Rearmament', German Studies Review, 7 (1984), 499-529.

${ }^{27}$ Peifer, 'Commemoration of Mutiny, Rebellion, and Resistance', p. 1038. 
higher echelons of the Wehrmacht associated with the 'good' soldierly (Prussian) tradition. ${ }^{28}$ While these films exculpate the Wehrmacht, Hake points out that the screen Canaris, Harras, and Stauffenberg are also ambivalent figures, negotiating the conflicting emotions of a West Germany undergoing a democratisation that has been forcefully initiated by the Western allies, particularly the Americans:

In the films under discussion, post-war audiences are invited to feel empathy with the members of the resistance, their professional dilemmas as military officers and their personal struggles as men fearing discovery and arrest. However, because of their association with political failure and military defeat, these men cannot be portrayed as wholly sympathetic figures. The assumption of shared values and beliefs is reserved for the supporting characters, the young officers $[\ldots]$ who are destined to become the citizens of a more democratic Germany. By contrast, the title characters must be eliminated as enemies: products of an authoritarian past and its antidemocratic traditions. ${ }^{29}$

I agree with Hake that these screen elite traitors are hardly figures of fulfilment or renewal. However, the elite traitor functions as a figure of transition in that his individual failure exculpates the majority's failure and yet confirms the general framework of unwavering loyalty to the nation repeatedly spelled out in 1950 s cinema. The Prussian screen traitors justify the committed treason with reference to Germany and thus re-imagine a national community which they see threatened by a group of Nazis.

\footnotetext{
${ }^{28}$ For a detailed discussion of the tropes of the rearmament discourse launched by politicians and the press that the films then took up, see Becker and Schöll, In jenen Tagen, p. 80.

${ }^{29}$ Hake, Screen Nazis, p. 69.
} 
The problem with the figure of the elite traitor is that it has little scope for action and easily perishes in the face of its own patriotic maxims. For as soon as the self is in any way threatened by the resistance, the elite traitor loses legitimation. This is continuously reflected in the films, as when the sabotage of aircraft in Des Teufels General that has long been undermining the war effort has claimed the death of one German pilot. Immediately, those responsible for the sabotage call themselves 'Mörder' ${ }^{30}$ And only by resorting to repeated invocations of Germany, is Stauffenberg able to justify the assassination plan and its potential cost for the self to his worried adjutant in Der 20. Juli: 'Und ich sage Ihnen, es ist zu verantworten - auf der einen Seite einige wenige, vielleicht auch 1 bis 2 Unschuldige, auf der anderen Seite Millionen. Soll man diese Millionen deshalb kaputt gehen lassen? ${ }^{31}$ The dilemma of the elite traitors in these films seems indeed less their 'authoritarian past and antidemocratic tradition, ${ }^{, 32}$ and more their fervent love of Germany which makes them acceptable to a post-war audience and at the same time hamstrung lest a single German victim invalidate the national cause.

30 'In Zuckmayers Bühnen-Original stieß der Widerstandskämpfer Oderbruch auf schroffe Ablehnung, da er durch seine Sabotage den Tod deutscher Soldaten in Kauf nahm. Das wurde in der Verfilmung dahingehend geändert, dass er zwar sabotiert, der Tod des Piloten aber die Schuld eines voreiligen Nazi-Offiziers ist.' Christian Bach, Keine Fragen, vorwärts Marsch! Der Zweite Weltkrieg und die Problematik seiner Darstellung im westdeutschen Kriegsfilm (Munich: Hochschule für Fernsehen und Film, 2005), p. 18. See also Becker and Schöll, In jenen Tagen, p. 89.

${ }^{31}$ Given the focus on self-restoration, it is not surprising that in Canaris a figure like General Hans Oster, who informed the enemy, was left out.

${ }^{32}$ Hake, Screen Nazis, p. 69. 
The apexes of the triangle of treason in these films are elite traitor, good self/German people, and bad self/Nazis, which leaves the elite traitor only the narrow national space to act. The common traitor on the other hand, who entertains relations with the other, has a wider scope for action albeit at the cost of the self. The national bonds and boundaries confirmed by the elite traitor as sacred and total - epitomized on screen in Stauffenberg's exclamation when facing the firing squad, 'Es lebe unser heiliges Deutschland!' - are 'expose[d] as particular and partial, not total' by the common traitor's interest in the other. ${ }^{33}$ 'Revealing to another [...] what had been thought to be a sacred or secret trust', ${ }^{34}$ is particularly painful as it facilitates a glimpse of the others and the wider reverberation of their suffering at the hands of the Germans. For thus profaning the national self, the common traitor is sentenced.

\section{The Common Traitor}

The common traitors on the 1950s screen are young(er) men who often belong to the lower ranks of the Wehrmacht and are always stationed at the front. They entertain relations with the enemy and are therefore seen as Landesverräter. In contrast to their elite counterparts, they are never part of oppositional networks but follow individual desires, which excludes them from patriotic causes; the German common traitor acts only from personal motives. Accordingly, the common traitor does not intentionally commit treason (cooperating with the foreign military, for example); he is only interested in 'human' matters. In line with this, the traitors in the three films chosen - part 2 of 08/15, Der Arzt von Stalingrad, and Unruhige $N a c h t$ - are first of all lovers who are involved with enemy women, often Soviet women.

The screen figure of the common traitor takes up and confirms notions of treason employed by the Nazis themselves, who subsumed a broad variety of insubordinate, humane

\footnotetext{
${ }^{33}$ Parikh, An Ethics of Betrayal, p. 12.

${ }^{34}$ Ibid..
} 
or oppositional behaviour under the crime of 'war treason', despite the fact that no actual treason had been committed. ${ }^{35}$ In the 1950 s this classification was endorsed particularly with reference to the danger that such behaviour allegedly caused for the other German soldiers, who were then idealized as 'comrades'. Helmut Kramer further interprets the defamation of the 'war traitors' as a sign of a 'tiefgehende Geringschätzung widerständigen Verhaltens einfacher Bürger überhaupt' ${ }^{36}$

Als ehrenhaft und zulässig galt damals [in the 1950s] wie heute den Rehabilitierungsgegnern nur der von den gesellschaftlichen Eliten geleistete Widerstand. Anerkannt wurde zunächst nur der militärische Widerstand des 20. Juli. Schon in den Widergutmachungsdebatten des Jahres 1952 ging es im Kern darum, ob jede Widerstandhandlung moralisch anerkannt und materiell entschädigt werden sollte oder nur solche, die in einem, im konservativen Sinne verstandenen 'nationalen Interesse' waren. ${ }^{37}$

While the different types of screen traitors reflect this debate, it would still be wrong to say that they replicate it. The focus on 'human' and individual motivation minimizes the political threat otherwise posed by the common traitor and at the same time grants him, if not political approval, then at least the audience's sympathies. Furthermore it is the common traitor who keeps memories of the other alive.

$08 / 15$

\footnotetext{
${ }^{35}$ See Kramer, 'Das letzte Gefecht', p. 89.

${ }^{36}$ Ibid., p. 93.

${ }^{37}$ Ibid..
} 
The 08/15 trilogy was extremely popular with German audiences: Christian Bach calls it a 'gigantischen Publikumserfolg' watched by 15 to 20 million Germans. ${ }^{38}$ In part 2 the main protagonists are at the Russian front in the winter of 1942, where they fight not so much the Soviets but the weather conditions and their new captain, Witterer, a typically cynical, cowardly and incapable superior. The Red Army occurs only in far-off gunfire and a brief tank episode. Just a handful of civilians represent the other and it is only one young woman, Natasha, who has real screen presence and voice.

Natasha is drawn to the German Lieutenant Wedelmann, yet the affair is not just politically impossible from the beginning but, more importantly, also de-legitimized by the film. This is because Wedelmann meets Natasha in a moment of serious crisis triggered by his superior:

WEDELMANN Wenn ich nicht mehr an den Führer glauben kann, woran soll ich mich dann halten?

VON PLÖNIES Wenn ich mal Scheiße sage, müssen Sie nicht gleich an Nationalsozialismus denken, Wedelmann.

Wedelmann's attraction to the other is motivated by his unsettledness within the group to which he belongs, which causes him to pursue individual desires. He wants to learn Russian and falls in love with his teacher Natasha. She falls in love with him, too, but the audience learns before Wedelmann that Natasha is also a soldier and is passing on information to the Red Army - however reluctantly - so that when the Wehrmacht wants to retreat secretly, it comes under Soviet fire. Wedelmann inadvertently 'betrays' his comrades because he, in the moment of crisis, forgets his national identity in favour of human identity: the information he

${ }^{38}$ Bach, p. 15. 
passes on is given to Natasha the lover, not the soldier. Natasha, on the other hand, knows where she belongs, despite a conflict of loyalty and translates the human message into military currency. In line with the general interpretation of the war in the 1950s films, this melodrama illustrates the war 'als Schicksal, als Drama, als Tragödie, als Überwältigende Geschichte, die dem einzelnen Menschen unentrinnbar auferlegt wurde'. ${ }^{39}$ However, it is even more interesting to see to what degree this sub-plot also reveals German aggression and arrogance.

The two lovers are not on an equal footing. Lieutenant Wedelmann is part of the occupying forces whereas Natasha belongs to those occupied and exploited by the Wehrmacht as forced workers. Wedelmann's desire for this other is not just caused by crisis; it is at the same time rooted in the feeling of superiority of the conqueror who perceives the other only as a mirror of his own wishes. Yet Natasha refuses to reflect Wedelmann's worldview; she turns the mirror and shows him his face as seen from the Soviet point of view:

NATASHA Früher hatte ich einen Samowar.

WEDELMANN Ja, ja ich weiß schon, die Deutschen haben ihn requiriert. Sie hatten auch viele Tassen und Gläser, die haben die Deutschen auch requiriert.

NATASHA Warum sagen Sie das? Ärgern Sie sich über sich selbst?

WEDELMANN Vermutlich haben die Deutschen auch Ihre Eltern tot geschlagen.

NATASHa So ist es. Genau so.

Significantly, Wedelmann himself introduces the topic, presenting it as a cliché to ironize the 'bad German soldier' as mere propaganda with which he assumes Natasha will disagree.

${ }^{39}$ von Hugo, 'Kino und kollektives Gedächtnis?', p. 461. 
Natasha's reaction, however, hints at the truth behind the cliché and challenges Wedelmann's stance of moral integrity.

The loss and suffering that the German invasion causes Soviet civilians also finds indirect expression in the discourse of war as consumerism. While Natasha lives with a little niece in a run-down, almost empty house, the Wehrmacht is shown to revel in luxury. A central part of the film revolves around Sergeant Platzek's provision store, which is not just crammed with basic army provisions but also includes livestock and luxury goods, many of which are explicitly marked as coming from occupied territories: French cognac, French soap and perfume, sparkling wine from the Crimea, and caviar malossol. All the film's principal characters - the 'bad lieutenant' Witterer, the 'good lieutenant' Wedelmann, the Prussian aristocrat and father-figure Colonel General von Plönies, and the 'citizens in uniform', Sergeant Asch, Corporal Vierbein, and Staff Corporal Kowalski - partake of this wartime consumerism and profit from it.

This is also the case with regard to the other commodity circulated: women. On the one hand, there are the Wehrbetreuerinnen. In a carnivalesque scene they arrive like socialites in fur and jewels, only to reveal themselves later as salacious performers for the soldiers. The 08/15-song, in particular, plays on war as sexual pleasure; the camera's focus on the women's breasts and bottoms anticipates their true purpose, for after the show they are spoiled with sparkling wine and chocolates while they themselves are being 'consumed' by the soldiers. War is shown as a sensual feast for the lower ranks, too. At the same time, the defeated enemy's women are also part of this network of consumption. When asked 'Handeln Sie auch mit Russenweibern?', Platzek identifies Natasha as 'Sonderverpflegung', a luxury to be enjoyed on special occasions. Wedelmann, who intends to 'relish this treat', tries to seduce Natasha in a similar manner to the seduction of the Wehrbetreuerinnen. Confronted by Natasha with evidence of German atrocities, he changes the subject and offers her a chocolate 
bar. Yet Natasha, unlike the German women, declines and offers it to her niece. This signals that Natasha cannot be 'consumed' completely, even though Wedelmann does get 'a taste' of her later on. Instead, the conflict is reinstated at the end when Wedelmann calls Natasha a spy and she calls him a robber. The 'good lieutenant' fails to present himself as harmless and innocent to the other.

The Soviet-German love affair is a frequent constellation and the soldier who enters it is typically deviant. He appears as weak, unstable, and egotistical; pursuing his individual desire he gives his comrades away but also enables the other to become briefly visible as a victim. This is also the case in Geza von Radvanyi's Der Arzt von Stalingrad, a prisoner of war film set in a Soviet camp. The German love-traitor Dr Sellnow is depicted as passionate, easily enraged and thus just as unstable as Wedelmann. As in $08 / 15$, the love affair facilitates the other's voice in an initial clash in which the Soviet experience is at least hinted at by the woman, Dr Kasalinskaja:

SELLNOW Aber diese Kranken sind auch Menschen, und glauben Sie mir, sie haben mehr verloren als die Gesundheit.

KASALINSKAJA Sie haben zu reden? Sie haben halbe Russland kaputt gemacht und jetzt weinen Sie, weil Sie es wieder aufbauen müssen? Die arme Deutschen! Was sie alles verloren haben! Und wir? Millionen haben alles verloren und haben nur noch ein Bild, genau wie Stabsarzt Böhler. Da, da schauen Sie, der [her father] war auch Arzt genau wie Sie, der wollte leben genau wie Sie. Er ist verhungert, elend verhungert und Sie haben ihn verhungern lassen. 
The love affair denotes betrayal in Der Arzt von Stalingrad, too, and leads to the death of the traitor. Although the common traitor is again an unintentional traitor and therefore not officially punished, according to film logic he is still unfit to rejoin the community.

Unlike Wedelmann, Sellnow does not commit treason by giving away military secrets, even accidentally. He is also not an traitor like his co-prisoner Grosse who passes the Soviet commander of the camp the names of mutinous POWs. Sellnow's case rather illustrates that the desire for the other counts already as a crime. When the other prisoners identify Grosse as snitcher, they kill him brutally; the attempt of the Soviets to discover the murderers fails as the Germans 'close ranks' and are ready to be punished together rather than 'betray one of their own'. This moment of closing ranks against the Soviets is presented as identity formative and includes all Germans except Sellnow, who is watching the decisive event from his Soviet lover's window. Stabsarzt Böhler, the main protagonist and father-like figure, reproaches Sellnow: 'Alle sind sie dagewesen, alle. Sie hätten sich glatt erschießen lassen [...] Nur einer hat gefehlt, Herr Oberarzt [Sellnow].' That Sellnow abandoned his comrades when they faced the Soviets is seen as treason. Consequently, Sellnow dies at the end of the film. Der Arzt von Stalingrad puts the message most pointedly: the individual has to serve the nation first and foremost without any reservation. The father-figure Stabsarzt Böhler sets the example. Asked by the Soviets to help a Soviet child, he replies: 'Solange ich meinen Kameraden da draußen nicht helfen darf, darf ich mir auch keinen "Privatpatienten" leisten.'

Von Radvanyi's film employs a number of strategies to de-legitimize the Soviet other and present it as not entitled to German sympathy, justification or responsibility. The depiction of the POW camp as a German concentration camp in particular undermines any claim of Soviet juridical or moral right. And yet this Cold War strategy does not seem to sufficiently ease the (West) German conscience. The melodramatic betrayal-by-love sub-plot 
serves as a reminder of a national taboo. The traitor-plot offers a way of admitting German guilt and denying it at the same time by denouncing the speaker as well as the listener. It is a highly ambivalent construction that acknowledges what must not be acknowledged and denies validity to an argument which nevertheless is compulsively repeated.

Falk Harnack's Unruhige Nacht promised a new approach to the war and the eastern front and one might therefore expect a different take on the traitor as well. Noticeably, the film employs a different narrative strategy: instead of relegating the betrayal-by-love into a sub-plot, the traitor and his story are developed as a case for reflection and thought at the centre of the film. This narrative importance also heightens the status of Soviet civilians as victims of German aggression and, linked to this, represents a moral call for German responsibility. ${ }^{40}$ However, the shifting of the friend/enemy divide is kept in check by new strategies of de-legitimation which work to render the common traitor as unethical after all.

\section{Unruhige Nacht}

Based on the successful 1949 novella by Pastor Albrecht Goes, Unruhige Nacht tells the story of the love-traitor Fedor Baranowski through the eyes of a sympathetic war chaplain ordered to accompany the young man to his execution. The film is set during one night in which the chaplain visits the convict and studies his file. The story of Baranowski, who deserted twice to live with a Soviet woman and thereby inadvertently gave military information away, unfolds in flashbacks, which follow the chaplain's reading and reflection. The film was expected to be an 'Anti-Hurra-Film' and counter 'die notdürftig mit pazifistischem Farnkraut abgetarnten Uniform- und Paradefilme[ ] der deutschen Filmindustrie ${ }^{41}$ of the 1950 s. When it was released, at least Gunter Groll, writing in the

\footnotetext{
${ }^{40}$ Kapzynski, p. 23.

41 ‘Kriegsfilm: Schluss mit Jubel’, Der Spiegel No 43, 22 October 1958, p. 68.
} 
Süddeutsche Zeitung, confirmed that the film had fulfilled these expectations and called it 'der mutigste, der folgerichtigste, der kompromißloseste und der unbequemste von allen Antikriegsfilmen, die in diesen Jahren gedreht wurden'. Groll saw Unruhige Nacht as a warning while 'die Donnerschnulzen Hurra [riefen]' ${ }^{42}$ However, most critics rated the film as well-intended at best. Erika Müller in Die Zeit thought the film withheld most of the truth which the novella had tried to expose:

Das menschlich so warme, anteilnehmende Berliner Publikum ertrug bei der Uraufführung diesen Film mit Haltung. Es antwortete mit Sympathiebekundungen für den Fahnenflüchtigen, die aber offensichtlich kein Politikum waren. Die Wirkung des Films ist stark, aber auch er enthüllt nicht alles. ${ }^{43}$

A harsh brief slating appeared in Der Spiegel accusing the film of miscasting, a faulty script, and deficient direction which 'vollzog schließlich die künstlerische Exekution der ambitiösen Film-Idee'. ${ }^{4}$

Despite the general disappointment with the film, its central problem was not discussed in the reviews although clearly pointed out by an early critic of the project. What the novella and even more so the script was reproached with in this critique was firstly the absence of any real conflict:

\footnotetext{
${ }^{42}$ Gunter Groll, 'Leise und deutlich "Unruhige Nacht”, Süddeutsche Zeitung, 3 November 1958.

${ }^{43}$ Erika Müller, 'Wunderkinder und Seelsorge', Die Zeit, 6 November 1958, p. 30.

${ }^{44}$ Wallis, 'Neu in Deutschland', Der Spiegel, 12 November 1958, p. 64.
} 
Beide Partner - Hitlerregime und evangelische Kirche - treten essentiell nicht in Erscheinung. Es handelt sich nicht um die Story eines kämpferischen Gegensatzes oder um die Herstellung weltanschaulicher Unterschiede. Es wird weder gekämpft noch bekannt, es gibt keine Entwicklung und kaum eine Schuld, - es bleibt die Aufzeichnung eines traurigen (durchaus nicht unruhigen) Tages aus dem Leben eines Kriegspfarrers, geschmackvoll, gefühlsstark, - aber auch sentimental und ein wenig kokett. ${ }^{45}$

Linked to the missing conflict and the lack of development was the second criticism that punishment for desertion is hardly specific to the Third Reich. Consequently, the recommendation given in this early assessment was to introduce

eine Schuld, mit der er [chaplain] später nicht fertig werden kann. Er hat - der Entscheidungen gibt es viele - tatsächlich versagt, er hätte kämpfen müssen, er hätte helfen müssen, wenn er von dem Unrecht überzeugt ist. [...] Neben dem um viele Etagen tiefer und aufregender zu führenden Konflikt des Pfarrers sollte auch der Konflikt des Deserteurs tiefer und zeitgebundener geführt werden. Er müßte an einem typischen Hitler-Befehl zugrunde gehen, an einer von oben verfügten Unmenschlichkeit, und nicht an einem Gesetz, das auch für jede demokratische Armee Gültigkeit hat. ${ }^{46}$

The obliteration of historical specificity was of course intentional, as a letter from Horst Budjuhn, the scriptwriter, to Günther Stapenhorst, one of the producers (of Carlton Film $\mathrm{GmbH})$, illustrates:

\footnotetext{
${ }^{45}$ Anon., 'Unruhige Nacht' (Kulturarchiv an der Hochschule Hannover: Nachlaß Filmaufbau GmbH Göttingen), FAB 146, p. 1.

${ }^{46}$ Ibid. p. 2.
} 
An der Poesie lasse ich nicht rütteln. Sie bleibt das Herzstück des Films [...]. Gewiss, er wäre in jeder Armee erschossen worden, aber in einem höheren, ethischen, vor allem christlichen Sinne bleibt die Erschießung Mord. Und dieser Mord wird heute wieder bejaht, wenn sich dieser Tage eine englische Bischofskonferenz zur Rechtfertigung des Atomkriegs bekannt hat. [...] Wir dürfen uns nicht mehr an den Hitlerkrieg klammern, er ist schon beinahe historisch uninteressant geworden. ${ }^{47}$

Budjuhn's reasoning circumvents exactly what the anonymous critic had demanded - the acknowledgement of the criminal character of the Nazi war. Rather than (retrospectively) recognising desertion and treason as rightful acts in the Nazis' war of annihilation, the traitor is confirmed as acting against the law and as therefore justly, if regrettably executed. The film, particularly due to its new narrative organization, highlights the traitor and allows a better understanding of Soviet suffering; at the same time this seems to necessitate an explicit and unrelenting judgment of desertion as infringement and unlawful act. ${ }^{48}$

More than the other screen traitors, Fedor Baranowski facilitates glimpses of the wartime hardship of Soviet civilians. German plundering and murder are indicated when Fedor meets Lijuba while ordered to 'organize' provisions for the army. On his errand he sees emptied Russian houses; the civilians lack clothes and food (while the Wehrmacht decorate their offices with Russian art and craftwork). When Fedor gives Lijuba a warm winter coat and her little son a pair of boots, she assumes that he has stolen them from other civilians. In this setting, it is only Baranowski who is concerned for the other's deprivation. This

\footnotetext{
${ }^{47}$ Letter from Horst Budjuhn to Günther Stapenhorst, 16.07.1958, (Kulturarchiv an der Hochschule Hannover: Nachlaß Filmaufbau GmbH Göttingen), FAB 146, p.2.

${ }^{48}$ This reflects the legal situation; Wehrmacht deserters were only rehabilitated in 2009.
} 
sympathetic disposition seems to make him the first 'Landesverräter turned ethical'. However, far from becoming a hero and new model of German post-war masculinity, ${ }^{49}$ Baranowski's increased moral and self-critical potential is more than ever branded as irresponsible by the film. The narrative order and the traitor's deviance serve all the more strongly to deprive him of his case.

Baranowski like all traitors is deviant, but he is the one whose deviance consists in immaturity. We learn of the young Fedor that he grew up out of wedlock and was raised by a neglectful mother; he has no trade, received no training and is generally perceived as childlike; he is often referred to as 'Junge' and 'Bengel'. That he has a Slavonic name and comes from East Prussia marginalizes him in the national context, particularly as the film takes pains to mention that, had Fedor been a legitimate child, he would have had his father's very German surname Hoffmann. While this blunt metaphor of privation already lessens the traitor's culpability, his potential to disturb and challenge the self is further reduced by his unsophistication: with Fedor the traitor figure changes in that his individual desire is presented as moral and deeply human, yet at the same time all intellectual competence to reflect on his decisions is removed. Fedor seems to act out of instinct when he 'betrays' the Wehrmacht twice to live with Lijuba. Their retreat to a hut in the woods is in the tradition of the idyll and its locus amoenus. There is a longing for peace and justice/égalité in this, yet its connotation of childishness undermines the critical stance. The arguments between the lovers Wedelmann/Natasha and Sellnow/Kasalinskaja give way to a total understanding between Fedor and Lijuba on 'purely human' grounds. Their simplicity and unsophistication grants conciliation and at the same time undermines it. Unlike Natasha or Kasalinskaja, who are educated, reflective and have moral controversies with their equally accomplished German lovers, Fedor and Lijuba only communicate about basic needs. This is echoed in their

\footnotetext{
${ }^{49}$ Kapzynski, p. 20.
} 
language proficiency: while Natasha and Kasalinskaja spoke very good German - albeit with an artificially thick accent - Lijuba and Fedor stick to basic vocabulary and rudimentary grammar.

Another way of undermining the potential threat arising for a German audience from Baranowski's treason is the narrative frame given to the army chaplain. It is through the latter that Baranowski's story is told. Indeed, Baranowski does not appear until 20 minutes into the film and we don't learn his story until another 20 minutes later. The chaplain is presented as a war-loathing, sympathetic character whose humanity and critical prudence offer him as the main character and the one for the audience to relate to - particularly in his inner conflict of understanding and sympathising with Baranowski and yet condemning desertion as

\section{Landesverrat:}

MASCHER Übrigens ein ordentlicher Junge. Ich habe immer gesagt: ,Schade um den Bengel.'A Aber Fahnenflucht - nee, da ist nischt zu machen.

PFARRER Für seine Freiheit muss man schon kämpfen, bevor es Landesverrat wird. Auch Baranowski ist ja nicht ohne Schuld und kein englischer Kaplan käme daran vorbei einen Fahnenflüchtigen auf seinem letzten Weg zu begleiten.

The chaplain thus gives the obedience of the German majority a kind and sensitive voice, particularly as he also offers common ground for national identity beyond the war: he, who has all the faculties that Baranowski lacks, is highly educated and sophisticated and provides Mozart, good wine, literature, and savoir-vivre of former times as markers of German identity from which Baranowski is as excluded as the 'bad Nazi' of the film. The chaplain's loyalty seems to lie with the individual soldiers, not the regime; however, he trusts the regime's laws, judgment, and files as he bases his own understanding of Baranowski on their documentation. 
The figure of the love-traitor in these West German films follows the rhetoric of national self-justification linked to the denial of the other albeit based on the demonstration of the other's suffering. All three films fail to recognize that the discussion of the Third Reich and the Second World War had to find its point of reference not in questions of national legality and coherence but of international law and human rights; Unruhige Nacht in particular illustrates the insufficiency of the national approach as it poses the question of justice with regard to the other but then fails to tackle them.

That the debate had to go beyond the national context had been stressed by prosecuting attorney Fritz Bauer, whose much quoted closing statement in the 1952 Remer trial not only rebutted the accusation of treason with regard to the 20 July plot as false, but also laid down the points of reference for judging guilt:

Das Gesetz findet dort seine Grenzen, wo es in Widerspruch zu den allgemein anerkannten Regeln des Völkerrechts oder zu dem Naturrecht tritt, oder der Widerspruch des positiven Gesetzes zur Gerechtigkeit ein so unerträgliches Maß erreicht, daß das Gesetz als unrichtiges Recht der Gerechtigkeit zu weichen hat. Wird der Grundsatz der Gleichheit bei der Satzung des positiven Rechts überhaupt verleugnet, dann entbehrt das Gesetz der Rechtsnatur und ist überhaupt kein Recht. ${ }^{50}$

While none of the films of the Kriegsfilmwelle revised their perspective, a TV production from 1960 did and even today Am grünen Strand der Spree comes as a shock when watched after the big-screen war-entertainment of the time. The mini-series takes up the relation between national self and its others and offers a modified, if not completely changed answer to the initial question: 'Ging nicht die nächste Pflicht, die gegen die eigenen Volksgenossen,

\footnotetext{
${ }^{50}$ Fritz Bauer, 'Eine Grenze hat Tyrannenmacht', Geist und Tat 7 (1952), 194-201 (p. 199).
} 
die eigenen Kameraden, der gegen fremde Völker voran?' Again, the question is reconsidered through the figure of the traitor, which borrows features of the common traitor discussed so far but also reflects back on the elite traitor.

\section{Am grünen Strand der Spree}

My final section focuses on the first two parts of this five-part series produced by the NWDR and broadcast by ARD in 1960: Das Tagebuch des Jürgen Wilms and Der General. Both films are set during the war in occupied Poland, parts of the Soviet Union and Norway. Even though only part 2, Der General, presents the figure of the traitor, both parts belong together in that Das Tagebuch des Jürgen Wilms - doubtlessly the most unsettling of the films - can be considered a preparation for the treason committed in Der General.

The common traitors looked at were younger soldiers at the front line/on foreign territory. Their treason was triggered by individual crises, which led them to pursue their own desires fulfilled in a love affair with the other. These relationships gave a glimpse of the suffering of the Soviet civilians at the hands of the Germans without, however, making this suffering an explicit concern; indeed its relegation into a sub-plot and the de-legitimation of the love-traitors reinforced a notion of German moral integrity. This changes when in Am grünen Strand der Spree the young German soldiers become first outsiders and then traitors not because they are emotionally unstable and therefore 'fall' for the other, but because they witness the other's pain and therefore find their notion of self undermined. This cautious and gradual reversal of cause and effect is prepared by a closer look at the other as well as the filmic reworking of the soldier from a figure of action to a figure of perception.

As indicated in the title, Das Tagebuch des Jürgen Wilms offers an individual's perspective on the war - mainly in Poland and parts of the Soviet Union. In the manner of the common traitor, the young Wilms is interested in the other and their language; consequently 
the perspective offered revolves around his efforts to decipher the other, to read their signs and lives. If such interest was seen as highly deviant in the films discussed before, it is now presented as open-minded and perceptive. The film re-establishes a link between language learning and empathising with the people and presents it as fundamentally human and beyond a love interest. The first decisive scene occurs when Wilms, searching a word in his Polish dictionary, looks up to see into the face of a Polish Jewish girl asking him for help. Just as Wilms remains a frequent camera eye for the audience, we also often see him watching; the emphasis on forms of seeing predetermines Wilms to become an eye-witness of the Holocaust on German screens, which culminates in a terrible, twenty-minute-long scene of mass murder 'in bis dato unbekannter Offenheit'. 51

Despite witnessing the Holocaust and understanding his own inactivity in the face of atrocities as cowardice and complicity, Jürgen Wilms does not desert from the Wehrmacht let alone join the other side. ${ }^{52}$ However, if one accepts that the successive mini-films have a progression built-in with regard to the individual's freedom and responsibility to act, then Lieutenant von Sternberg's support of the Norwegian liberation army in Der General takes up where Wilms left off, and draws the consequences from the atrocities which Wilms witnessed.

\footnotetext{
${ }^{51}$ Christoph Classen, 'Back to the fifties? Die NS-Vergangenheit als nationaler Opfermythos im frühen Fernsehen der Bundesrepublik’ (March 2004), www.zeitgeschichte-online.de [accessed 15 February 2014]. For a summary of the press reviews see also Lars Koch, 'Das Fernsehbild der Wehrmacht am Ende der fünfziger Jahre', in Der Holocaust im Film. Mediale Inszenierung und kulturelles Gedächtnis, ed. by Waltraud Wende (Heidelberg: Synchron, 2007), pp. 71-84.

${ }^{52}$ For a discussion of elements that relativize the involvement and guilt of the Wehrmacht see Classen and Koch.
} 
In line with the figures discussed, von Sternberg is a minor character whose treason forces the other members of the military staff to take sides. Like Baranowski and Sellnow, Sternberg as a Baltic German belongs to the national margins, which is further stressed by his interest in languages that he shares with Wilms and Wedelmann; we learn that Sternberg understands Estonian, German, Swedish, Danish, and Norwegian, with the latter language, typically, linked to a love interest, as Sternberg too has a relationship with a local woman. Yet emphasis is first of all put on Sternberg's international grounding which saves him from getting caught in fatalistic notions of Germanness and in complicity with murder and injustice. While in the other films treason was seen as inexcusable if explainable misbehaviour, Sternberg's treason is for the first time intentional and appears as a clearsighted and justified decision which is further underlined by its purely ethical rationale and the absence of emotional crisis and mental instability or immaturity. In the rendition of judgement Sternberg is quoted as having

selbst betont, er halte sein Tun für gerechtfertigt. Er sei Balte und sei im guten Glauben an die Sendung der deutschen Kultur in die Wehrmacht eingetreten. Der Nationalsozialismus habe aber diesen seinen Glauben, mit dem er aufgewachsen sei, restlos erschüttert.

In a number of instances Der General seems like a reversal of Unruhige Nacht which is particularly striking with regard to the relation between traitor and army chaplain. Sternberg is presented as upright and determined, which includes his rejection of Christian absolution. Instead of looking for comfort from a priest, he escapes prison and his death sentence. The nonchalance with which the chaplain in Unruhige Nacht justifies the death of the traitor, is ironized in Der General when judge and chaplain wonder 'was hätt ich denn machen sollen?' while the young soldier has long changed sides. 
The main character of the film is Sternberg's antagonist, a general. He looks on Sternberg as a son but immediately arrests him when catching him red-handed informing the Norwegians. With General Johann Beatus Freiherr von Hach und zu Malserhaiden the Prussian discourse so prominent in the depiction of the elite traitors is taken up again and revised vis-à-vis the common traitor. In line with the wider debate, the film disclaims the Third Reich as Prussia's 'true essence' or successor: 'Wie es denn überhaupt das Dritte Reich falsch deuten hieße, wenn man in ihm eine entsetzliche Sublimierung preußischen Wesens sehen wollte, wie das die Alliierten einst taten.' However, Prussia is not confirmed as a suitable tradition either. According to the film, the Prussian 'essence' is not patriotism but a systematically cultivated death-wish linked to an obsession with constant fighting:

Dabei ist es weniger ihre Kampf- und Mordlust, die abstoßend wirkt, als vielmehr eine Art systematisch gepflegter Todessehnsucht. Ein manerierter Kult mit der eigenen Formfestigkeit und Selbstbeherrschung. Es sind sozusagen die Calvinisten des Preußentums. [...]

While thus Prussia is freed from blame for National Socialist crimes, it is by no means quoted as a role model, which is particularly important when we learn that the general is linked to the 20 July plot. The film directly confronts treason with reference to the self and treason with reference to the other and in this comparison presents the Prussian elite as impotent, while the young internationally-rooted generation is seen as capable and is given a future. The best the old elite can do before seeking death in battle and thus fulfilling their 'Prussian nature' is to help the young. Atoning for the arrest of Sternberg, the general arranges for the young lieutenant to escape to safety and thus helps the first Landesverräter to survive if not on cinema than at least on TV screens. 


\section{Conclusion}

The common traitor like the elite traitor holds a distinct position in the landscapes of war in West German film production of the 1950s. He exists in variations though central elements remain, as films such as Der Fuchs von Paris ${ }^{53}$ or Die letzte Brücke $e^{54}$ confirm: The common traitor is young and part of the fighting units; the treason is triggered by relations with the enemy though it is always unintentional; the focus is on the individual as 'human', which is seen in conflict with its national identity and political convictions; the praise of humanity does allow a glimpse of the political reality, however brief it may be. Thus Yvonne asks Captain Fürstenwerth in Der Fuchs von Paris: 'Ach, Sie sind nicht gern Soldat? Muss doch Spaß machen: In Häusern wohnen, die man beschlagnahmt, Wein trinken, den man requiriert, sich anzueignen, was einem nicht gehört.'

As negotiator between self and other, the common traitor is hopelessly lost for the national collective as he marks the collective's failure to engage with the atrocities committed in the recent past. He fulfils this function as marker of national failure not because he sets a positive example for dealing with guilt and responsibility but because he personifies various conflicts that impede such an engagement. His deviant character and behaviour have been discussed as metaphors for the challenge arising for the self from the lost war, the exposure and discussion of atrocious crimes, and the following occupation and division of the country. Furthermore, the common traitor can also be understood as exposing a lack of acceptable models for engaging with this past, as is indicated by the gender implications of the figure. In all the cinema films discussed, it is a woman who gives voice to at least some of the suffering at the hands of the Germans, never a Soviet or French man even where they play central parts as in Der Arzt von Stalingrad and Der Fuchs von Paris. The connotation of suffering as

\footnotetext{
${ }^{53}$ Der Fuchs von Paris, dir. by Paul May (Constantin Film, 1957).

${ }^{54}$ Die letzte Brücke, dir. by Helmut Käutner (Columbia Filmgesellschaft mbH, AU 1954).
} 
'feminine' stains the common traitor who in terms of genre tends to be a melodramatic character (unlike the elite traitor who is tragic). In this context it is noteworthy that the earliest German-speaking film dealing with the topic, Helmut Käutner's Die Letzte Brücke, had a female traitor. In Käutner's film a nurse at the front is abducted by Yugoslav partisans who need a doctor for their injured. Torn between her ethical obligations as a doctor and her national duty, she complies with her ethical responsibility and accepts to die as a national outcast. Käutner's film too relegates political discussion into mise-en-scène and asides and focuses its narrative on 'human' drama. However, Käutner's melodrama fulfils genre expectations by presenting a woman as the exponent of political conflict in the realm of emotion. In comparison, that West German war films present men in stark emotional conflict labelled in political terms as Landesverräter points to the emasculation that the end of the war brought, and marks a lack of accepted political models of action that would found a new masculinity in relation to the victim other.

University of Reading

Department of Modern Languages and European Studies

Dr Ute Wölfel

Whiteknights, PO Box 218

Reading RG6 6AA

u.wolfel@ reading.ac.uk 